\title{
Augustine's anti-ideological political realism in De Civitate Dei
}

\section{O realismo político anti-ideológico de Agostinho em De Civitate Dei}

Davi Chang Ribeiro Lin

\begin{abstract}
Augustine's De Civitate Dei, or The City of God, written between (413427), expresses a political realism that makes love the subversion of ideological projects of power. Disordered loves tend to idolatry which stimulates political ideology; but the Augustinian politics of the affections carries an intrinsic critique to this logic of domination. The motif of how love subverts pretenses to power will be discussed through three main parts. Firstly, De Civitate Dei builds an argument that deglamorizes the Roman Empire, arguing that Rome's decline is due to their pursuit for vainglory and lust for domination. Secondly, since this idolatrous polytheistic society is bound to enslavement to its pride, Augustine presses his readers to love God and his eternal city. Thirdly, as Augustine deconstructs Roman patriotism and questions its idolatries, one must think on the relevance of the Augustinian vision to the deglamorization of contemporary political ideologies. By associating idolatry with the libido dominandi, the lust to dominate, and by criticizing the violence and the dynamics of domination and enslavement which founded the civitas terrena, Augustine discards ideological and theocratic attractions that rise from assigning a messianic role to politics.
\end{abstract}

Keywords: Augustine of Hippo. Politics. Love. The City of God. Idolatry. 


\section{Resumo}

A obra De Civitate Dei, ou A Cidade de Deus, escrita por Agostinho de Hipona entre (413-427), expressa um realismo político que faz do amor a subversão de projetos ideológicos de poder. Amores desordenados tendem à idolatria que, por sua vez, estimula a ideologia política; mas a política agostiniana dos afetos carrega uma crítica intrínseca à lógica da dominação. $\mathrm{O}$ contexto de como o amor subverte as pretensões ao poder será discutido em três partes principais. Em primeiro lugar, De Civitate Dei constrói um argumento que retira a idealização do Império Romano, visto que o declínio de Roma é consequência de sua busca pela vanglória e desejo de dominar. Em segundo lugar, como essa sociedade politeísta idólatra está fadada à escravização de seu orgulho, Agostinho encoraja seus leitores a amarem a Deus e sua cidade eterna. Em terceiro lugar, visto que Agostinho desconstrói o patriotismo romano e questiona suas idolatrias, deve-se pensar na relevância da visão agostiniana para a desidealização das ideologias políticas contemporâneas. Ao associar a idolatria à libido dominandi, e ao criticar a violência e a dinâmica de dominação e escravização que fundaram a civitas terrena, Agostinho descarta as atrações ideológicas e teocráticas que surgem ao atribuir um papel messiânico à política.

Palavras-chaves: Agostinho de Hipona. Política. Amor. A Cidade de Deus. Idolatria.

\section{Introduction}

Augustine of Hippo (354-430 A.D.), bishop, monk, theologian and philosopher, lived in a time of social and political transformations by the end of late antiquity. Among the most significant events of Augustine's lifetime is a tragic event that expressed the declining condition of Roman politics and its distance from a "glorious" past: the sacking of Rome in 410 by barbarians, namely Alaric and the Visigoths, an event which prompted not only migratory consequences but controversies and resentments between different actors in Roman society. The sacking of the "eternal city", Roma aeterna, was of enormous significance to its populace. This event prompted Augustine's response in a long and arduous work, "magnum opus et arduum" called De 
Civitate Dei, or The City of God, written between (413-427). This masterpiece of Western literature is divided into two parts, the first consisting of 10 books (I-X), offering a far-reaching response to the allegations that Christianity was responsible for Roman collapse. The second one (books XI-XXII), advances his model of the two cities: terrena civitas and civitas caelestis, which separates Church and the State and develops foundational distinction between the earthly and the heavenly city, an antitheses centered around its loves, "two cities have been formed by two loves: the earthly by the love of self, even to the contempt of God; the heavenly by the love of God, even to the contempt of self". ${ }^{1}$

For Augustine, every community or people is united around the common objects of love. ${ }^{2}$ As the structures that order community life reflect the affective life, societal organization articulates the quality of loves of a whole society. This cultural organization can be disordered or, to some extent, express the ordo amoris, an ordered love towards God and loving all things through God. A disorderly affective life gives creation the glory that is due only to the Creator, making idols and false gods: it is idolatry and has the potential to become disordered power projects. The Augustinian idea of disordered love has an intimate connection to the biblical perspective on idolatry, giving to creation what is ascribed to the Creator, which feeds into political ideology. The link between idolatry and ideology is an outcome of Augustinian political thought, for although ideologies are based on created goods, they deviate from the truth by giving it a status of ontological primacy, extolling it to the detriment of the rest of creation. ${ }^{3}$

As the Roman calamity strengthened criticism of Christianity, much has been said about how Augustine's De Civitate Dei carries an attempt to defend it against pagan accusations, as Augustine himself puts it, "from this world's city there arise enemies against whom the City of God has to be defended". ${ }^{4}$ If on one hand pagans blamed Christians for having forsaken the worship of "pagan" gods, they also suggested that Christian ethics, that of a weak crucified saviour, had destabilised and brought frailty to the Roman Empire. Augustine would then respond based on pagan sources, subverting their narrative of success by arguments from on their own cultural background,

\footnotetext{
${ }^{1}$ AUGUSTINE, De Civ. Dei 14.28.

${ }^{2}$ AUGUSTINE, De Civ. Dei 19.24.

${ }^{3}$ KOYZIS, D., Visões e ilusões políticas, p. 228.

${ }^{4}$ AUGUSTINE, De Civ. Dei 1.1 .
} 
drawing from Roman history and its main characters, from philosophical schools and Roman religious' practices. Right from the start, in the prologue, Augustine questions the Roman quest for domination, contrasting Vergil's line "To spare the conquered, and beat down the proud" to the biblical affirmation that God is gracious to human humility, "God resists the proud, but he gives grace to the humble", a line from the epistle of James.

Yet there is another subtle yet crucial conceptual change, one that shifts the definition of politics from a just community (as Cicero argued in De re publica) to a people united by the common objects of their love. By placing the affective component at the center of political life, Augustine finds a way to displace the empire's self-aggrandizing narrative and opens a window to propose a Christian alternative to the social and political disaster brought by the sack of Rome in 410. Furthermore, as Augustine retells the history of Rome placing its idolatries and its disordered loves at the center of political life, it becomes evident that his critique does not bear consequences solely to the Romans themselves, but it has wide-ranging implications as anti-ideological political realism beyond its century. Luigi Alici suggests that Augustine's civitas Dei peregrina, the pilgrim City of God, carries precious antibodies against idolatries and the enzymes of virtuous sociality into "the peace of Babylon". 5

This article argues that Augustine's political realism makes love the subversion of ideological projects of power, and therefore, fosters a Christian political vision that is able to expose ideologies as idolatries. Disordered loves tend to idolatry which in turn stimulates ideology; but the Augustinian politics of love carries an intrinsic critique that subverts the ideological projects of power. The motif of how love subverts pretenses to power will be discussed through three main parts. Firstly, De Civitate Dei deglamorizes the Roman Empire. Augustine constructs a narrative of deglamorization, arguing that their pursuit for vainglory and dominion has been the cause of Rome's decline. Secondly, Augustine exposes the idolatry within Roman culture. Since this idolatrous polytheistic society is bound to enslavement to its pride, Augustine presses his readers to love aright. Thirdly, building from the previous sections, this work will discuss Augustine's anti-ideological political realism. By connecting idolatry with the libido dominandi, the desire to dominate, and by criticizing the violence and enslavement is which founded the civitas terrena,

\footnotetext{
${ }^{5}$ ALICI, L., The Violence of Idolatry and Peaceful Coexistence, p. 216.
} 
Augustine discards ideological temptations that seek to ascribe messianic roles to politics.

\section{The subversion of power projects: the deglamorization of the Roman Empire}

In the first part of De Civitate Dei, namely its first 10 books, Augustine primarily builds up an argument that deglamorizes the Roman Empire in order to dismantle the self-inflated Roman worldview about its celebrated past. Rome's self-understanding reproduced a narrative of glorious history from an identification with a group of heroes, a self-congratulatory story. Augustine recounts the decline of the Roman Empire by deconstructing its idealization: he destroys the myth of a pure Rome, narrating the sordid details of its history and exposes that the state contradictorily has to do things that it condemns. The accomplishments of Rome are disconnected to the virtues of times past and related to the Romans' good fortune, obsession, greed, and the lust to dominate.

De Civitate Dei was written as a reply to those who said that Christianity was responsible for the sack of Rome in 410, leading Augustine to reinforce that Rome's injustice is the reason for its fall, inviting them for a less selective reading of their own history. Rome did not grow and develop due to its civic virtues or generosity, but it is born through a murder and develops through injustice. In questioning the citizens' indiscriminate affection for the Roman Empire, Augustine claims that justice never prevailed in Rome and its founders were not deserving heroes. Since its beginning Rome had been established upon the violence of a fratricide, for as its founding tale narrates, Romulus killed his twin brother Remus and became Rome's first king. From its foundation it has neglected the need to care for what is the essence of life, the heart, interiority, virtuous character. Rome had embraced the opposite, an incorporation of moral evils, blind and unaware of what truly makes men evil. ${ }^{6}$

The Augustinian perspective displaces an ontology of politics from the more positive quest for justice to the more realistic and yet shadowy affective life of its citizens. Augustine chose to reject Cicero's self-affirming and somewhat optimistic vision of what constitutes a city, a bond established

${ }^{6}$ AUGUSTINE, De Civ. Dei 3.1 . 
by a mutual sense of justice. For Augustine, the pursuit of justice is not the main motivation that keeps together political communities, but its selfish appetites, cravings and fears. In Augustine's political realism, state affairs are not necessarily different in their essence from criminals who desire to rule, dominate and subjugate others. In a telling moment which questions the hidden motivations, Augustine recalls the encounter between Alexander the Great and a captured pirate in order to reinforce their common egotistic aspirations,

For it was a witty and a truthful rejoinder which was given by a captured pirate to Alexander the Great. The king asked the fellow, "What is your idea, in infesting the sea?" And the pirate answered, with uninhibited insolence, "The same as yours, in infesting the earth! But because I do it with a tiny craft, I'm called a pirate: because you have a mighty navy, you're called an emperor". ${ }^{7}$

Augustine knew by experience the self-centered and selfish ambitions that drove human beings in the Roman Empire, both in a personal and a collective level. On a personal level, he was part of the provincial families of North Africa who sought upward mobility through an increased association to the dominions of imperial power. ${ }^{8}$ Augustine, a gifted son trained in the art of rhetoric, carried his family expectations to climb the social ladder. In a hierarchical society such as fourth-century Roman Empire, prestige was bound to study and professional opportunities, and marrying the right patron or "father-in-law" would have to be delayed until Augustine's peak in worldly career. Consequently, the relational part of his existence was subservient to the values of individual success and power. Augustine's Confessions is a story of loss, of wavering relationships, either by death or for the sake of upward mobility.

This self-centered quest for success was also part of cultural collective identities and undergirded political and military projects. Corruption and an infinite appetite for control were expressed by Roman citizens in its libido dominandi, an indiscriminate desire for power and control, which created disequilibrium. This society had been seized by an obsession for domination, expressed by their Latin words of imperium and dominium. As Augustine suggests, a man eager for domination is to be regarded as "worse than the beasts,

\footnotetext{
${ }^{7}$ AUGUSTINE, De Civ. Dei 5.4 .

${ }^{8}$ COOPER, K., Love and Belonging, Loss and Betrayal in the Confessions, p. 71.
} 
in his cruelty or in his self-indulgence. Some of the Romans were men of this kind, who, while caring nothing for the opinion of others, were possessed by the passion for domination. History shows that there were many such". ${ }^{9}$

For the Bishop of Hippo, the Roman Empire did not deserve the devout patriotism of its inhabitants. Faced with the injustice of its history, the devotion of its citizens was disproportionate, as a manifestation of a disorderly love for the Roman State. Augustine pondered that Rome's belief on its privileged benefits from the gods is not only a huge deception, but it directed this society to massive idolatry. The glamourized conviction that the pantheon of gods had favored the Romans turned them into immoral worshippers of all kinds of created things. Augustine's De Civitate Dei not only critiques the patriotism and glamorization of the Roman Empire, but the pagan worship of idols, which he saw as a dire consequence of the vainglory and misplaced loves.

\section{The subversion of power projects: the enslavement of idolatry and the need to love aright}

A people is a gathering of individuals around their objects of love, and consequently, better objects of love will eventually improve social organization; the more disordered the objects of love, the worse the interaction of these people. In Augustine's eyes, therefore, the drama of Roman collapse is far more profound than barbarian invasions or dysfunctional collaboration between groups in Roman society. Rome is an idolatrous civilization, corrupted by its lust to dominate, the libido dominandi. Augustine denounces the inversion of freedom and slavery which brings the tragic destiny for societies of disordered loves.

Idolatrous human beings are hostages to what is fleeting, for they love material things and fail to love what is eternal. Already in Confessions (397-401), Augustine described the consequences of a divided inner life which led him to idolatry and distancing from God, which makes him beg for a life of single-hearted service. ${ }^{10}$ Augustine's biographical account in Confessions tells about Augustine's distance from God's virtuous seeds of love and cultivating pride, superbia. In the famous scene of the theft of pears, the theological meaning underneath is not to be neglected: humankind

\footnotetext{
${ }^{9}$ AUGUSTINE, De Civ. Dei 15.19.

${ }^{10}$ AUGUSTINE, Conf. 10.35.56.
} 
wishes to substitute God in overriding the instructions, replacing the field owner. Augustine's story portrays how original sin is also endorsed in his divided and idolatrous existence, for in his prideful rebellion establishes himself as the possessor of the field. His is the search for vainglory, pursuing dominion in a restless existence. But when Augustine was found by the grace with converted his heart, he was also invited to love God above all else. Augustine came to realize that when one reaches ordered love, ordo amoris, the soul is reestablished to the proper position, and therefore contributes to the realization of peace. ${ }^{11}$ If in Confessions Augustine had already linked restlessness to idolatry and peace to right love, this connection would be later expanded and nuanced in The City of God.

Idolatry in De Civitate Dei is a consequence of sin, of the vanity of pride, of seeking the creation instead of the Creator, distancing oneself from the true God and tragically being enslaved to demonic powers. ${ }^{12}$ This vicious circle of captivity which degenerates into idolatry is the result of vainglory and the sin of pride upon which the city of men has been established. Lost in veneration of false religion, Romans created their own gods, a mere projection of their images and appetites, tragically bounding them to demonic powers, "the demon attached to an image by an impious art has been made a god by man, but a god for this particular kind of man, not for all mankind. What sort of a god then is this who could only be made by a man who is in error, who lacks faith, who is estranged from the true God?". ${ }^{13}$

Due to the consequences of being enslaved to idolatry, Augustine stresses the need to promote the ordering of loves and develop virtues, such as humility and subjection. Since human beings primarily need humility, authority and coercion still have a function as a remedy to pride because of sin. Augustine is not against state regulations which guide the wicked by the use of force. Even the virtuous need to be disciplined and learn the path of subjection, to foster humble life. Faced with the need for virtuous love, the Augustinian opposition is between political virtue and political vice. Augustine's politics, therefore,

\footnotetext{
${ }^{11}$ AUGUSTINE, Conf. 13.9.10.

12 "For by worshipping them he was drawn into fellowship with them, and I do not mean fellowship with senseless idols, but with crafty demons. For what are idols but the things of which Scripture says, 'They have eyes, but they do not see', and all the rest that can be said of material things, bereft of life and sense, however skilfully fashioned? But the unclean spirits, bound to these images by this wicked art, had brought the souls of their worshippers into a wretched captivity, by forcing them into their fellowship". AUGUSTINE, De Civ. Dei, 8.24.

${ }^{13}$ AUGUSTINE, De Civ. Dei, 8.24.
} 
is a politics of the soul, and the vices and pestilences attack not primarily the bodies but far more disastrously, their characters. ${ }^{14}$

The ontological principle capable of guaranteeing human happiness (individual and social), is love carrying a double function, constituting both the weight and the measure of all the ethical-moral foundations of humanity. ${ }^{15}$ This principle is based on the double commandment of caritas: "Love the Lord your God with all your heart and with all your soul and with all your mind. This is the first and greatest commandment. And the second is like it: love your neighbor as yourself' (Mt 22,37-38). As Ramos points out, the double commandment of Christian love, a summary of Christian law that includes mercy and meekness, will never be harmful to the state. ${ }^{16}$ The members of the pilgrim City of God and its specific earthly city are compelled to take the love of God, through benevolence, through doctrine, through discipline, patiently tolerating and enduring evil men if they can't be corrected.

Even though the city of men is founded upon a self-centered idolatrous love, the pilgrim to the celestial city is attentive to the higher love in its relationship with God, lives and abides in Him. Since differing loves founded antithetical cities, one for the love of God and the other for the love of self, ${ }^{17}$ the process of ascension to the divine guides the proper human search and stimulates its original love. When a man approaches God, the same image that he has taken with him since birth is renewed. ${ }^{18}$ Progressing in knowledge and justice, this human being moves to higher heights, loving God and "collecting the scattered traces of his being". ${ }^{19}$ God is man's place, and his city is destiny which humanity was originally destined for.

\section{Augustine's anti-ideological political realism}

As Augustine deconstructs Roman patriotism and questions its idolatries, one must think on the contemporary relevance of the Augustinian vision to the deglamorization of contemporary political ideologies. Idolatry as disorderly love for the Roman Empire has its modern counterpart in the nation-state,

\footnotetext{
${ }^{14}$ AUGUSTINE, De Civ. Dei 3.17.

${ }^{15}$ COSTA, M. R. N., Introdução ao pensamento ético político de Santo Agostinho, p. 14.

${ }^{16}$ RAMOS, M. T., A Ideia de Estado na Doutrina Ético-Política de Santo Agostinho, p. 270.

${ }^{17}$ AUGUSTINE, De Civ. Dei 14.28.

${ }^{18}$ PIERETTI, A., Doctrina antropológica agostiniana, p. 342.

${ }^{19}$ AUGUSTINE, De Civ. Dei, 11.28.
} 
the "worship" of a country or nation. Nationalism has been a strong political ideology in Europe and around the world since the 19th century, being a relevant causal element towards the beginning of the two world wars in the $20^{\text {th }}$ century. According to Reyes Mate, the European and Western political tradition has historically been marked by the understanding of the political as the distinction between friend and enemy. ${ }^{20}$ The enemy was often understood as the foreigner, the other nation. In this inflection, politics does not foster reconciliation. Augustine's anti-ideological political realism has a contemporary relevant counter-claim: faith in the Triune God makes Christianity a subversive faith in the face of national ideologies and the claims of the kingdom of "one people". In fact, the multiplicity in oneness of the civitas Dei peregrina is a beautiful collection of all races and resists the flattening of cultures. The diversity of languages, cultures and nations is an expression of bonding cross-national unity that resists monolingual projects of dominion,

While this Heavenly City, therefore, is on pilgrimage in this world, she calls out citizens from all nations and so collects a society of aliens, speaking all languages. She takes no account of any difference in customs, laws, and institutions, by which earthly peace is achieved and preserved - not that she annuls or abolishes any of those, rather, she maintains them and follows them (for whatever divergences there are among the diverse nations, those institutions have one single aim - earthly peace), provided that no hindrance is presented thereby to the religion which teaches that the one supreme and true God is to be worshipped. ${ }^{21}$

According to James K. A. Smith, Augustine's political position is antithetical and political in its form incorporated in the earthly city and any quest for building empires. ${ }^{22}$ Smith's pertinent discussion illuminates the dynamics of love in De Civitate Dei for the Augustinian political vision. He suggests that since Augustine neither fully condemns nor supports civic virtues, two interpretive emphases have emerged, those that accommodate

\footnotetext{
${ }^{20}$ MATE, R., Memoria de Auschwitz, p. 82.

${ }^{21}$ AUGUSTINE, De Civ. Dei, 19.17: Haec ergo caelestis civitas dum peregrinatur in terra, ex omnibus gentibus cives evocat atque in omnibus linguis peregrinam colligit societatem, non curans quidquid in moribus, legibus institutisque diversum est, quibus pax terrena vel conquiritur vel tenetur, nihil eorum rescindens vel destruens, immo etiam servans ac sequens, quod licet diversum in diversis nationibus, ad unum tamen eumdemque finem terrenae pacis intenditur, si religionem, qua unus summus et verus Deus colendus docetur, non impedit.

${ }^{22}$ SMITH, J. K. A., The Politics of Desire, p. 220.
} 
Augustine to a certain political neutrality and another that emphasizes the Augustinian antithesis to the idolatry of a political ideology. He positions himself in favor of the latter. Augustine never denied the role of the state as a promoter of earthly peace and its relative value to promote it. Nevertheless, Augustine highlighted the ambiguity of peace brought by Rome. If on one hand the barbaric incursions helped him to recognize in practice the value and necessity of the state, Augustine is very skeptical against political propaganda or idolatry of the Empire.

By associating idolatry with the libido dominandi, the lust to dominate, and by criticizing the violence and the dynamics of domination and enslavement which founded the civitas terrena, Augustine discards theocratic attractions that rise from assigning a messianic role to politics. ${ }^{23}$ As Luigi Alici points out, it is not the Civitate Dei which is founded on a mixture of religion and politics, but the civitas terrena. Roman gods did not precede the civitas; on the contrary, the city of men comes first and creates its own gods. And, since the civitas asserts to be self-legitimating, it manipulatively assigns the divinities in a kind of a relativistic pantheon, carrying a disintegrative drive of amor privatus. ${ }^{24}$

The reception of Augustine's political thought throughout the centuries has frequently faced the risk of identifying the Civitas Dei with the Church or Christendom. This was not a reading that Augustine himself assumed (for the Church is a mixed body, corpus permixtum), but a possible association of his thinking when reread in the light of the total identification of society, church and state, as in medieval Europe. For Augustine, members of the two cities exist in the visible church, mixed together. Therefore, no visible society or institution can be identified with any of the cities. The distinction is eschatological, not political, those destined to live with God and those who are not. The members of the cities are together in what he calls a saeculum, the time dimension in which politics takes place.

Another possible misunderstanding, one that Augustine was already aware in his lifetime, is that the Christian future expectations can mistakenly bring an excessive emphasis on the City of God as an eschatological salvation without regard to present political implications. In this narrow disengagement

${ }^{23}$ For relevant works about Augustine's distancing from a triumphalistic state, ELSHTAIN, J. B., Augustine and the Limits of Politics; and also HEYKING, J. V., Augustine and Politics as Longing in the World.

${ }^{24}$ ALICI, L., The Violence of Idolatry and Peaceful Coexistence, p. 215. 
to present life, there is no continuity between the eschatological City of God and the Kingdom of God already present on earth. An appropriate reading of De Civitate Dei recognizes Augustine's Christian responsibility for the two cities. ${ }^{25}$ History is the stage on which the Kingdom, in its mustard seed, in the weakness of humility and not in the prideful palace, has already taken root in this world. Pilgrims, in itinere, sojourning on earth in via to the celestial city are called to participate in political life in the earthly city with the hope of dwelling in God and their city, cultivating the virtues of love and working towards the shalom of present-day life, working for the earthly city while waiting for the consummation of history.

As human beings are marked by lust and desire for domination that characterizes the city of men, the state is necessary to regulate the lives of individuals. It, however, remains limited in its ability to bring happiness, as political structures are hostage to the disordered passions of its inhabitants. The state in Augustine's thought is only a moral instrument, and has no absolute value, but a relative one, measured in relation to the teleological-supernatural dimension. ${ }^{26}$ God established political authority, and that power comes from God who ordained it as a remedy for sin. Nevertheless, there is a huge limit in the political capacity to bring happiness, for politics in the earthly city carries the narrow horizon of terrestrial peace and does not know the harmony of the true eternal city. Augustine recognizes the need for authority as an answer to sin, but also suggests that humans must follow the direction of leaders even if they had no sin. Augustine does not claim the absence of leadership or anarchism; but that in a prelapsarian situation, prior to the human fall, this organization of authority would not necessarily be a coercive political authority, but probably a family and paternal leadership. ${ }^{27}$

Despite his severe attacks on Roman patriotism, Augustine's interest is not so much in political institution per se, nor in responding to the origin and purpose of the state. His primary goal is not to defend a state theory, as it appears implicitly rather than explicitly, but his concern is for human pilgrimage in this earthly city, as one waits for the true happiness to be reached in the Heavenly City. Thus, political theory appears indirectly, as a consequence of his interest in eudemonia, the quest for happiness. The state can either act as a moral instrument that supports humanity to a righteous life, or reproduce injustice and foster the lust

\footnotetext{
${ }^{25}$ For further discussion, see BRAATEN, C. E.; JENSON, R. W. (Eds), The Two Cities of God.

${ }^{26}$ COSTA, M. R. N., Introdução ao pensamento ético político de Santo Agostinho, p. 14.

${ }^{27}$ WEITHMAN, P., Augustine's Political Philosophy, p. 238.
} 
for control and domination, the libido dominandi, one that distances humanity to achieve true happiness which is only attainable in eternal life.

\title{
Conclusion: love at the center of political life
}

For Augustine, ordered love subverts ideological projects of power, but disorderly love causes empires to fall. Politics expresses the continuity between the ethical and moral dimension of the individual and the foundations of political order. Furthermore, Augustinian thought carries the antidote against a selective or ideological reading of history, questioning misplaced authorities and idolatries, having a prophetic role against the political ideologies that seek to control the loves of its populace. As Mathewes points out,

\begin{abstract}
Augustinians will try to get them to remember their histories less selectively, for history is the register of faith for Augustine. They urge this more comprehensive memory in order to induce both sides to reform their too tidy and too easy perceptions of reality, to confess with humility to a faith in the Lord of history, whose true face remains crucially hidden, and to acknowledge that we remain pilgrims along the way in a story whose author we are not. We may need force to secure order, but we shall never in this dispensation proclaim, "Mission Accomplished!". ${ }^{28}$
\end{abstract}

Christians breathe as paradoxical citizens: by God's eternal grace, they have received their passport towards eternal peace, "a republic to the citizenship of which faith, hope and charity admits us" (Ep. 138.17), but by their mortal condition they live in the fleeting peace of earth. Nevertheless, despite its temporary character, Christians are entitled to uphold the peace on earth, one that is a signum of what is to come, as an expression of their hope, faith and love. As Luigi Alici points out:

What distinguishes the Christians is not an exterior separateness, nor a theocratic claim to have "captured" coexistence. They share with everyone the harshness, the disorder and the injustice that reign in history, but they are called to the unheard of task of converting all of these things, so to speak, from within. ${ }^{29}$

\footnotetext{
${ }^{28}$ MATHEWES, C. T., An Augustinian Look at Empire, p. 300.

${ }^{29}$ ALICI, L., The Violence of Idolatry and Peaceful Coexistence, p. 216.
} 
Although Augustine did not devote himself to philosophical work on political theory per se, it is possible to recognize a distinct Augustinian approach; it is based on theology and psychology, as well as ethics, social theory, philosophy of history, ${ }^{30}$ placing love at the center of political life. His vision fosters a conception of resistance that subverts attempts to reproduce a project of power in the social order. As a people is a multitude of rational creatures united by a common agreement in the objects of their love, Augustine emphasizes that true love is the one who gives worship to God. Since Rome and no other political system gives to God the glory that is due to Him, the city of men will always be in need of true justice. For Augustine, love is the ontological element that allows a happy life, but this fullness will only be achieved in a teleological-supernatural dimension. Recognizing the achievement of political salvation as an eschatological event, De Civitate Dei is a book that re-reads the present in the light of the future, in the expecting hope for the light of true love that will prevail.

\section{Bibliographical references}

ALICI, L. The Violence of Idolatry and Peaceful Coexistence: The Current Relevance of Civ. Dei. Augustinian Studies, v. 41, n. 1, p. 203-218, 2010.

AUGUSTINE. The Confessions. The Works of Saint Augustine: a translation for the 21st Century. New York: New City Press, 2012. v. I/1.

AUGUSTINE. The City of God. London: Penguin, 2003.

BRAATEN, C. E.; JENSON, R. W. (Eds.). The Two Cities of God: The Church's Responsiblity for the Earthly City. Grand Rapids: Eerdmans, 1997.

COOPER, K. Love and Belonging, Loss and Betrayal in the Confessions. In: VESSEY, M. (Ed.). Companion to Augustine. Chichester: Wiley-Blackwell, 2012. p. 69-86.

COSTA, M. R. N. Introdução ao pensamento ético político de Santo Agostinho. São Paulo: Loyola, 2009.

ELSHTAIN, J. B. Augustine and the Limits of Politics. Notre Dame: University of Notre Dame Press, 1995.

${ }^{30}$ WEITHMAN, P., Augustine's Political Philosophy, p. 234. 
HEYKING, J. V. Augustine and Politics as Longing in the World. Columbia: University of Missouri Press, 2001.

HOLY BIBLE: New International Version. Colorado Springs: Biblica, 2011. KOYSIS, D. Visões e ilusões políticas. São Paulo: Vida Nova, 2014.

MATE, R. Memoria de Auschwitz: actualidad moral y política. Madrid: Trotta, 2003.

MATHEWES, C. T. An Augustinian look at Empire. Theology Today, v. 63, n. 3, p. 292-306, 2006. Disponível em: <https://doi.org/10.1177/0040573606 06300302>. Acesso em: 31 jul. 2020.

PIERETTI, A. Doctrina antropológica agustiniana. In: OROZ RETA, J. (Ed.). El pensamiento de San Agustin para el hombre de hoy: la filosofia agustiniana. Valencia: EDICEP, 1998. p. 329-404. v. I.

RAMOS, M. T. A Ideia de Estado na Doutrina Ético-Política de Santo Agostinho: um estudo do epistolário comparado com o "De Civitate Dei". Porto Alegre: Letra e Vida, 2015.

SMITH, J. K. A. The Politics of Desire: Augustine's Political Phenomenology. In: BOEVE, L.; LAMBERIGTS, M.; WISSE, M. (Eds.). Augustine and postmodern thought: a new aliance against modernity? Leuven: Peeters, 2009. p. 211-235.

WEITHMAN, P. Augustine's Political Philosophy. In: STUMP, E. (Ed.). The Cambridge Companion to Augustine. Cambridge: Cambridge University Press, 2001.

\section{Davi Chang Ribeiro Lin}

Doutor em Teologia pela Katholieke Universiteit Leuven, Bélgica e pela Faculdade Jesuíta de Teologia e Filosofia Docente no Seminário Teológico Servo de Cristo

São Paulo / SP - Brasil E-mail: davichangbh@gmail.com

Recebido em: 31/07/2020

Aprovado em: 05/11/2020 